\title{
Editorial v. 27, n. 2 (2015)
}

Apresentamos o volume 27.2 de Fractal: Revista de Psicologia. O periódico passou por algumas reformulações e prossegue, compromissado com a publicização de textos em que distintos estudos sobre a subjetividade assumem protagonismo. Convidamos leitores e colaboradores a lerem os textos publicados no volume atual, além de submeterem seus manuscritos em nossa plataforma. Mesmo com dificuldades inerentes ao esforço de consolidação no cenário dos periódicos científicos em Psicologia, Fractal: Revista de Psicologia reafirma sua missão a cada volume publicado. Com a renovação de sua equipe editorial, o periódico sustenta sua singularidade política na manutenção de sua metodologia de avaliação de manuscritos e no incentivo à publicização de pesquisas e reflexões relevantes que acusem a magnitude dos estudos da subjetividade. Boa leitura!

\section{Marcelo Santana Ferreira}

Editor de Fractal: Revista de Psicologia. 